\title{
Isolation of Natural Inhibitors of Papain Obtained from Carica papaya Latex
}

\author{
Rubens Monti ${ }^{1 *}$, Jonas Contiero ${ }^{2}$ and Antonio José Goulart ${ }^{1}$ \\ Universidade Estadual Paulista "Júlio de Mesquita Filho" - ${ }^{1}$ Faculdade de Ciências Farmacêuticas, Departamento \\ de Alimentos e Nutrição, Rod. Araraquara-Jaú, Km 1, CEP 14801-902, Araraquara - SP, Brazil, e-mail: \\ montiru@fcfar.unesp.br; ${ }^{2}$ Instituto de Biociências, Departamento de Bioquímica e Microbiologia, Rua 24-A, 1515, \\ CEP 13500-900, Rio Claro - SP, Brazil
}

\begin{abstract}
Studies were carried out to natural papain inhibitor from papaya latex. Fresh latex from green fruits of Carica papaya was collected and immediately transported in ice bath to the lab, from which three fractions with inhibitor effect of esterase papain activity were isolated by latex dialysis, Sephadex G-25 gel filtration and ionic exchange chromatography in SP-Sephadex C-25. The isolated fractions, identified as inhibitors I and II, showed a negative reaction with ninhydrin; however, the fraction identified as $P$-III showed positive reaction with ninhydrin. Kine tics data showed non-competitive inhibition (inhibitor I) and uncompetitive (inhibitors II and P -III).
\end{abstract}

Key words: Esterase activity, natural papain inhibitor, protease inhibitor

\section{INTRODUCTION}

The papaya tree (Carica papaya) is cultivated in tropical countries and the fruit is appreciated by its flavor as well as by its easy digestion and nutritive value. The latex from green fruits contains a mixture of cysteine endopeptidase (Dubois et al., 1988), such as papain EC 3.4.22.2 (Mitchel et al., 1970), chymopapains (EC 3.4.22.6) A and B (Watson et al., 1990), papaya endopeptidase II, papaya endopeptidase IV (Barret and Buttle, 1985; Ritonja et al, 1989), and Omega endopeptidase (Dubois et al., 1988). Papain is a proteolytic enzyme widely used in both food industry and research laboratories. The occurrence and purification of natural inhibitors of proteolytic enzymes have been described in the literature for a long time (Learmonth, 1951; Whitaker and Bender, 1965; Heinrikson and Kézdy, 1976;
Kopitar et al., 1978). Hanada et al. (1978) isolated thiol proteinase inhibitor (E-64) from a culture of Aspergillus japonicus TPR-64. The purification and some characteristics of thiol proteinase inhibitors, such as papain, ficin and bromelin, were described in the literature (Järvinen, 1979; Rele et al., 1980; Vartak et al., 1980; Sasaki et al., 1981; Tanigushi et al., 1981; Norioka et al., 1982). Tamai et al. (1981) found an inhibition of the papain activity by analogous of E-64 optically active (EP-475). They showed that the SH groups of the papain decreased parallel to the lost of the activity when incubated with quantities corresponding to the analogous EP-475, suggesting that this inhibitor linked to the active thiol group in the proportion mol per mol. The synthesis of proteinase inhibitors is known to be induced in some plants by mechanical injury and by insect attack or microorganisms (Ryan and An,

\footnotetext{
*Author for correspondence
} 
1988). A number of gymnosperm and angiosperm seeds were examined and it was found that they had a wide variation in trypsin inhibitor content. Papain inhibitor content of the same seeds showed smaller variation. Fernandes et al. (1991) suggested that the former was associated to physiological/metabolic processes while the latter was associated to defense mechanism. Hines et al. (1992) made a screening for cysteine proteinase in 44 vegetables. Papain was inhibited by soybean hypocotyls and cotyledon extracts. Protopeptides released during the activation of some proteinase zymogens may act as efficient enzyme inhibitors. The mechanism of the interaction between proteolytic enzymes and protein inhibitors were presented by Mosolov (1994). Such zymogens can be considered as covalently enzyme-inhibitor complexes. A review about the structural basis of the endoproteinase-protein inhibitor interaction was recently published by Bode and Huber (2000). These authors described that living organisms used protein inhibitors as a major tool to regulate the proteolytic activity of proteinases .In the procedure according to Kimmel and Smith (1954) six fractions were obtained from the purification of dried latex by using essentially salt fractionating in the presence of cysteine. Alternative purification has been reported. Monti et al. (2000) described a method of crystallizing papain from fresh papaya latex without using high concentration of salts or thiol-containing substances such as cysteine and dithiothreitol. Crystallized papain was obtained by this method in the form of a complex with natural inhibitor existent in latex, which could be removed by dialysis. This work shows results from partial purification of papain inhibitors and kinetics studies.

\section{MATERIALS AND METHODS}

\section{Inhibitors extraction}

Papain crystallization studies from fresh latex of Carica papaya were described by Monti et al. (2000), where the presence of natural inhibitors complexed to papain was detected. To extract the inhibitors in this work, the latex extract had its $\mathrm{pH}$ adjusted to 9.0, centrifuged and the supernatant was dialyzed in distilled water $(19 \mathrm{~mL}$ of extract to $50 \mathrm{~mL}$ of water) at $4^{\circ} \mathrm{C}$ during $72 \mathrm{~h}$. The water of the dialysis with the inhibitors was lyophilized and the dried material obtained was re-dissolved in 2.5 $\mathrm{mL}$ of water milli-Q.

\section{Filtration in Sephadex G-25}

Samples of $2.5 \mathrm{~mL}$ of the inhibitors solution, obtained as described above, were submitted to filtration columns of Sephadex G-25 (120 x 1.5 $\mathrm{cm})$ using as diluent a $0.05 \mathrm{M}$ ammonium bicarbonate buffer with flow of $30 \mathrm{~mL} \cdot \mathrm{h}^{-1}$ and fractions of $3.0 \mathrm{~mL} /$ tube were taken in Frac-200 collector (Amersham-Biosciences). The inhibitory activity was detected in the elute after lyophilization up to the elimination of all ammonium bicarbonate. The material obtained was re-dissolved in water and samples were assayed with papain in a $0.1 \mathrm{M}$ sodium phosphate buffer $\mathrm{pH}$ 8.0. For each experiment carried out, a control tube was made, containing just the enzyme in its proper buffer.

\section{High voltage electrophoresis}

High voltage electrophoresis was made at $\mathrm{pH} 2.1$ using the inhibitors I, II, III in Whatman paper 3 $\mathrm{MM}, 57 \mathrm{~cm}$ length and $10 \mathrm{~cm}$ in one of the edges; at $\mathrm{pH} 3.5$ and 6.5 the samples were applied 28.5 $\mathrm{cm}$ from the edge. The electrophoresis was carried out in electrophoresis Savant flask, with water circulation, with difference potential of $3,000 \mathrm{~V}$, using acetic acid-formic acid buffer $\mathrm{pH} 2.1$ and acetic acid-pyridine $\mathrm{pH} 3.5$ and 6.5. After the runs at $\mathrm{pH} 2.1$ and 3.5, the paper was dried and pulverized with $0.2 \%$ ninhydrin $+1 \%$ pyridine in acetone whereas in electrophoresis at $\mathrm{pH} 6.5$ just $0.2 \%$ of ninhydrin in acetone was used. The unveiling, that is, the appearance of the violet color was carried out at $60^{\circ} \mathrm{C}$. The bands of positive ninhydrin electrophoresis were eluted from the paper with water and tested to verify to which of them would correspond to the inhibitors.

\section{Chromatography in SP-Sephadex C-25}

Samples of $0.2 \mathrm{~mL}$ of the solutions containing inhibitors, obtained by filtrations in gel Sephadex $\mathrm{G}-25$, were applied in columns $(35 \times 0.8 \mathrm{~cm})$ containing gel SP-Sephadex C-25, pre-equilibrated with $0.05 \mathrm{M}$ formic acid buffer $\mathrm{pH} 2.6$, collecting fractions of $1 \mathrm{~mL} /$ tube. Elution were promoted using a $0.1 \mathrm{M}$ ammonium formiate buffer $\mathrm{pH}$ 3.5. Fractions of $1 \mathrm{~mL} /$ tube were collected and were analyzed in spectrophotometer Ultrospec 1000 (Amershan-Bioscences) at $250 \mathrm{~nm}$. The fractions with papain inhibitory activity were mixed and lyophilized. 
Papain activity in absence and presence of natural inhibitors I, II, and III

Papain activity was determined according to Kirsh and Igelströn (1966) with N-carbobenzoxiglycil pnitrophenyl ester (Z-Gly-pNP) and also using $\alpha-\mathrm{N}$ benzoyl-L-arginin ethyl ester (BAEE) as substracts (Jacobsen et al., 1957). The reactions were carried out in a thermostatic cuvette at $25^{\circ} \mathrm{C}$. A Beckman model SS-2 potentiometer sensitive to variations of 0.01 units in $\mathrm{pH}$ was used and Tris was added with a Nimetrics microsyringe capable of measuring amounts up to $0.1 \mu \mathrm{L}$. The solution was thoroughly mixed by constant shaking and protected against atmospheric molecular oxygen by constant bubbling with nitrogen. Papain activity $3 \times 10^{-6} \mathrm{M}$ or $5 \times 10^{-5} \mathrm{M}$ was incubated at $25^{\circ} \mathrm{C}$ with volumes of inhibitors I, II and III separately and in duplicates, in increasing order $\left(\mathrm{A}_{250}\right.$ varying between 0.009 and 0.1 ) during 45 minutes under nitrogenous atmosphere. After this time, samples were taken and the esterase activity was measured at different substrate concentrations, according to the description above. The enzyme used in these experiments was always activated with DTE and filtrated in Sephadex G-25 as described by Monti et al. (2000). The stability was also verified as the time went on, pre-incubating at the beginning and at the end of each experiment. The initial rate of reaction was calculated directly from the linear portion of the curves for substrate hydrolysis in function of time, and the catalytic constant for BAEE was determined by the ratio between maximum velocity and active enzyme concentration. Km and Vmax for papain and papain plus natural inhibitors were determined according to the method of Lineweaver and Burk, (1934).

\section{RESULTS}

The inhibitors obtained by dialysis were analyzed regarding to their inhibitory power in esterase papain activity (Table1) and the results indicated a decrease up to $75 \%$ of the activity, using small inhibitors aliquots. Samples of the inhibitors were submitted to filtration in Sephadex G-25. The filtration revealed the presence of four peaks through the lectures at $250 \mathrm{~nm}$ and the enzyme was strongly inhibited with the elutes of the fraction 93 up to 110 (Fig. 1). Three columns were made and the total volume of these fractions was lyophilized, re-dissolved in $2.5 \mathrm{~mL}$ of water milli-Q and rechromatographed in the same conditions. This second chromatography confirmed the presence of inhibitors in fractions 86 up to 111 (Fig. 2). They were mixed, lyophilized and re-dissolved in $2.5 \mathrm{~mL}$ of water milli-Q.

The inhibitors obtained in the re-chromatography were analyzed by electrophoresis at $\mathrm{pH}$ 6.5. This experiment unveiled a positive ninhydrin dot in the original point where the sample was applied. At $\mathrm{pH} 3.5$ a small migration occurred to the negative pole, although without a clear separation. Moreover at $\mathrm{pH} 2.1$, there was a separation of the three substances that migrated towards the negative pole, confirmed by duplicate (Fig. 3).

Based on the data obtained by electrophoresis, chromatography experiments in SP-Sephadex C-25 were made. These results revealed the separation of three peaks with papain inhibitory activity. Inhibitors I and II did not link to the resin and were eluted separately soon after the void volume of the equilibrium buffer, but the inhibitor III was adsorbed on the resin and was eluted with the $0.1 \mathrm{M}$ ammonium formiate buffer $\mathrm{pH} 3.5$ (Fig. 4). Similar results were obtained in three identical columns. The fractions containing the inhibitors I, II, III were re-chromatographed separately in the same conditions mentioned above, and lyophilized and re-dissolved in water milli-Q.

Table 1 - Esterase papain activity measured at different inhibitors concentrations.

\begin{tabular}{cccc}
\hline Inhibitors $(\mu \mathbf{L})$ & Kcat.s $^{-1} / \mathbf{m o l}^{\text {protein }}$ & Kcat.s $^{-1} / \mathbf{m o l ~ S H}$ & Inhibition $(\%)$ \\
\hline 0 & 3.94 & 6.68 & - \\
10 & 1.97 & 3.34 & 50.0 \\
20 & 1.52 & 2.58 & 61.4 \\
40 & 1.15 & 1.95 & 70.9 \\
60 & 0.98 & 1.65 & 75.3 \\
\hline
\end{tabular}

Kcat was determined using the substrate Z-Gly-pNP $2 \times 10^{-4} \mathrm{M}$, enzyme concentration $2 \times 10^{-8} \mathrm{M}$ in $0.1 \mathrm{M}$ sodium phosphate buffer in $0.001 \mathrm{M}$ EDTA, pH 7.0; ionic strength 0.3 in acetonitrile $6.7 \%$; temperature $25^{\circ} \mathrm{C}$. 


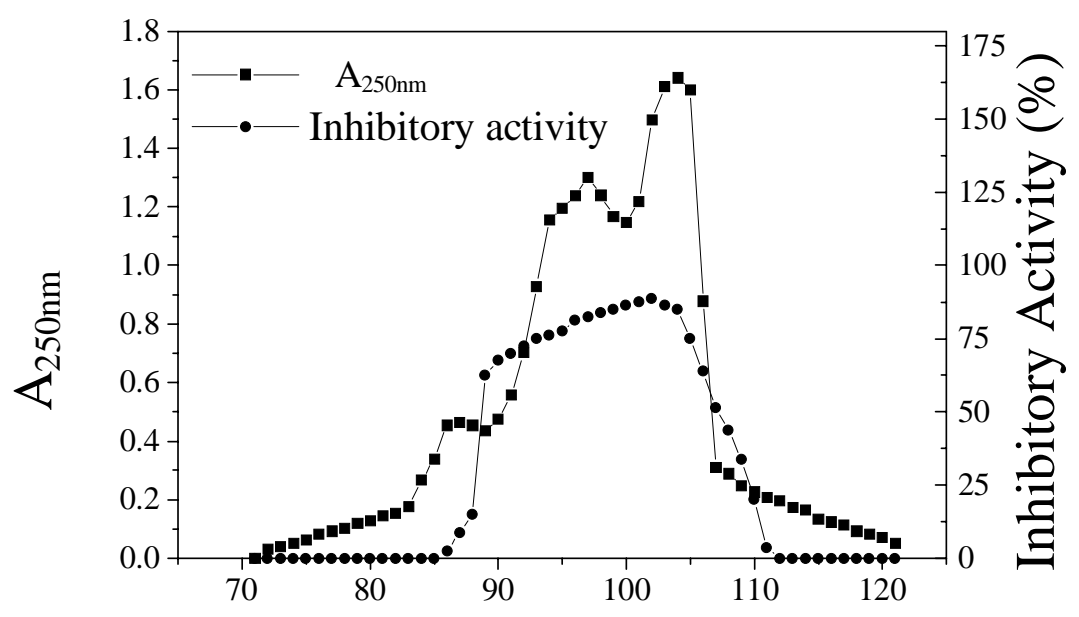

Fraction number

Figure 1 - Gel filtration in Sephadex G-25 (120 x 1.5) eluted with $0.05 \mathrm{M}$ ammonium bicarbonate buffer, fractions of $3 \mathrm{~mL} /$ tube.

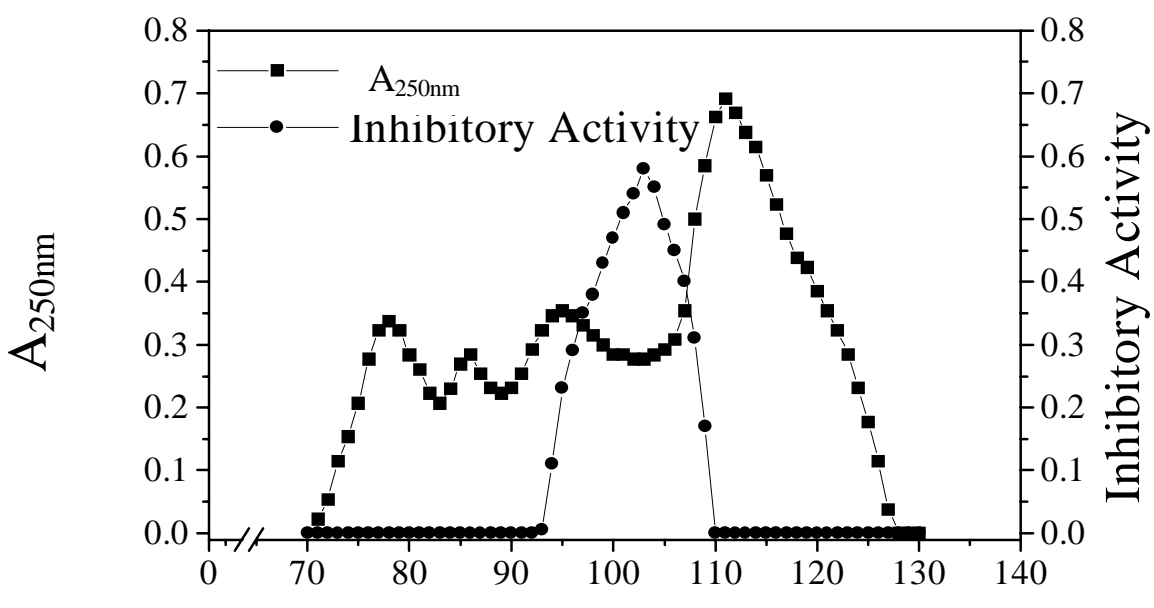

Fraction number

Figure 2 - Gel filtration in Sephadex G-25 $(120 \times 1.5 \mathrm{~cm})$ eluted with $\mathrm{H}_{2} \mathrm{O}$; flux: $20 \mathrm{~mL} / \mathrm{h}$; Fractions: $3 \mathrm{~mL}$. 


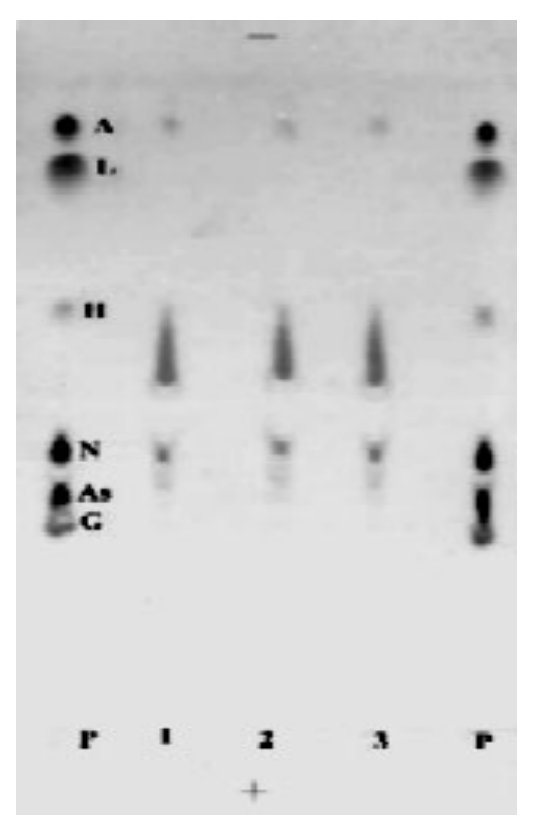

Figure 3 - Paper high voltage electrophoresis at $\mathrm{pH} 2.1$ of the sample obtained by Sephadex - G25 filtration; samples $1 \mu \mathrm{L}$ in triplicate. $\mathrm{P}$ : Standard (A-arginine; L-lysine; H-histidine; $\mathrm{N}$-neutral; As-aspartic acid; G-glutamic acid); 1: inhibitor I; 2: inhibitor II; 3: inhibitor III.
Inhibitor III showed positive reaction towards ninhydrin confirming its peptidic nature, while inhibitors I and II showed negative reaction. Due to the fact that inhibitor III had a peptidic nature, it was submitted to high voltage electrophoresis at $\mathrm{pH} 2.1$, revealing the presence of at least two ninhydrin positive fractions (Fig. 5). In similar electrophoresis without staining, the bands were eluted from the paper separately and submitted to inhibition tests; the higher mobility band was designed as Inhibitor P-III. This inhibitor was characterized and compared to inhibitors I and II partially purified. Then to verify the three natural inhibitors light absorption spectrum, a scanning spectrophotometry was made at 220 and $440 \mathrm{~nm}$ of length wave. Inhibitor P-III showed a maximum absorption peak at $275 \mathrm{~nm}$, while inhibitors I and II showed light absorption at $250 \mathrm{~nm}$, but did not show a defined peak.

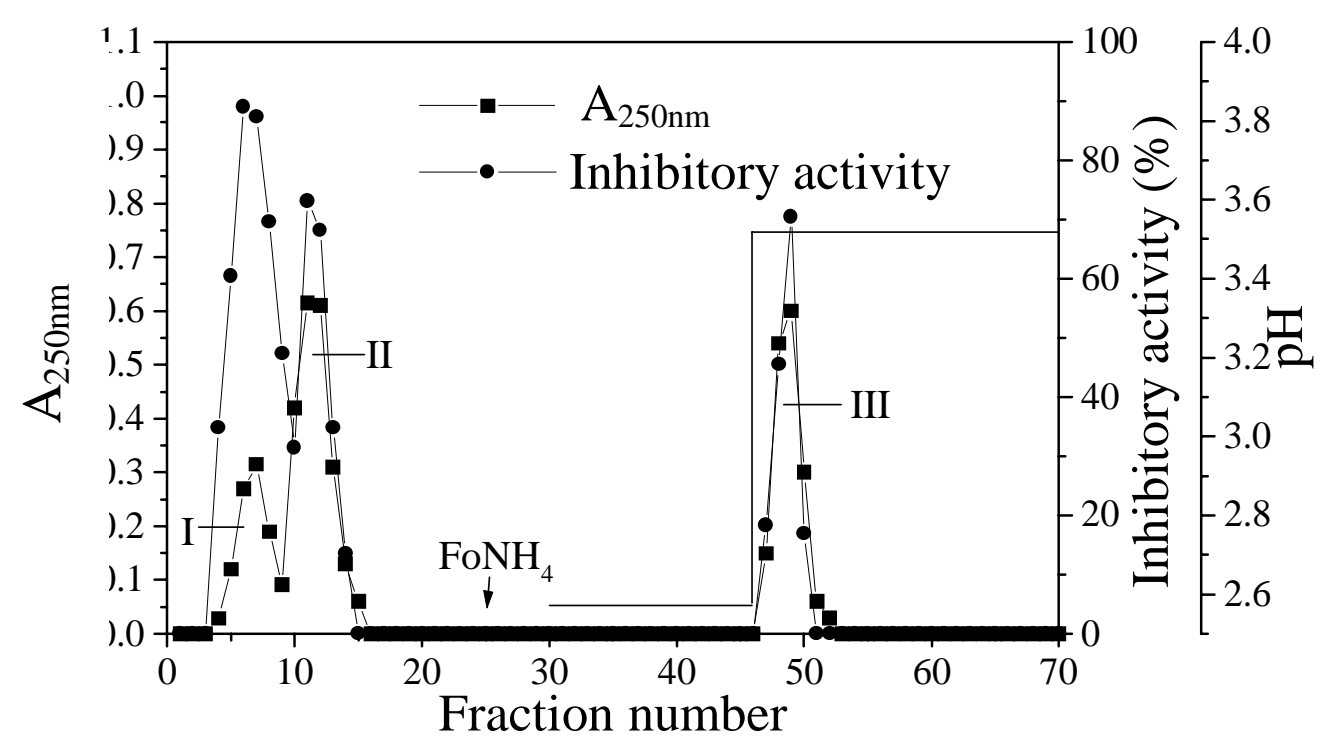

Figure 4 - Chromatography in SP-Sephadex C-25 $(35 \mathrm{x} 0.8 \mathrm{~cm})$ equilibrated with $0.5 \mathrm{M}$ ammonium formiate buffer, pH 2.6. Flux: $20 \mathrm{~mL} / \mathrm{h}$; fractions: $1 \mathrm{~mL}$. The inhibitor III was eluted with $0.1 \mathrm{M}$ ammonium formiate buffer, $\mathrm{pH} 3.5$. Samples obtained in fractions 86-111 from Fig. 2. 


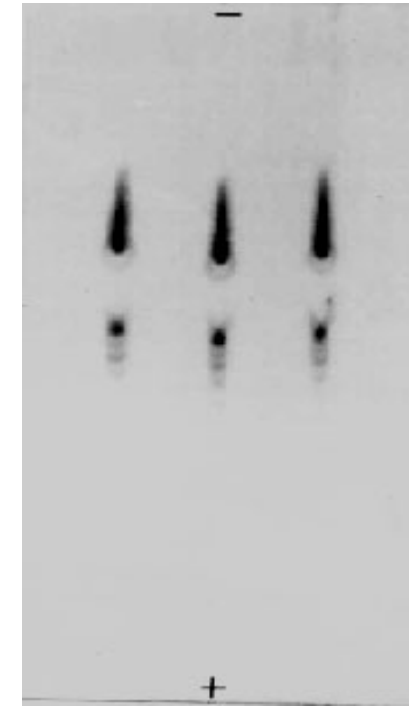

Figure 5 - Paper high voltage electrophoresis at $\mathrm{pH} 2.1$ of inhibitor III.
Papain kinetic studies were carried out using carbobenzoxyglycyl-p-nitrophenyl ester (Z-glypNP) as substrate and the inhibitors solutions in the necessary concentrations to inhibit $50 \%$ of the esterase papain activity, determined at $250 \mathrm{~nm}$ (Fig. 6). This procedure was necessary because the molecular mass of the inhibitors have not been determined yet.

$\mathrm{Km}$ and Vmax values were determined using $\alpha-\mathrm{N}$ benzoyl-L-arginine ethyl ester (BAEE) as substrate in the absence or presence of inhibitors, as showed on Table 2. Inhibitor II showed higher inhibitory power of the esterase papain activity followed by inhibitors I and P-III. The results allowed to determine that inhibitor I showed noncompetitive inhibition but on the other hand allowed to determine that inhibitors II and P-III showed uncompetitive inhibition (Table 2).

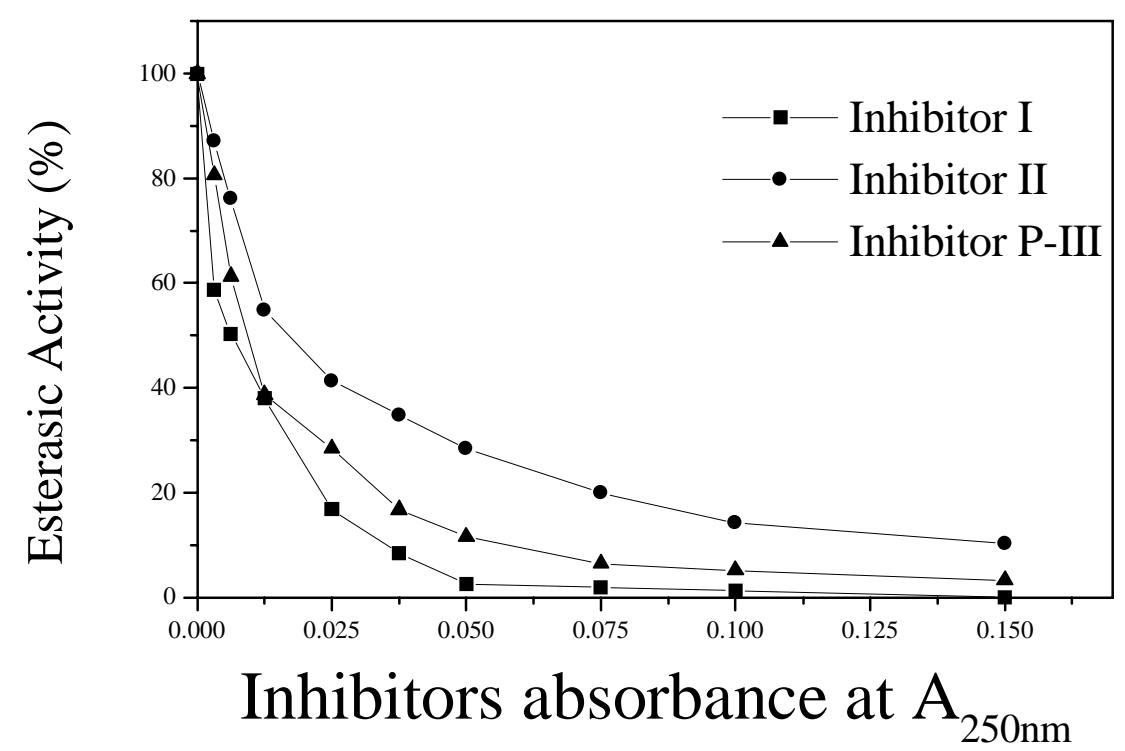

Figure 6 - Estimation of the inhibition of the esterase papain activity by natural inhibitors I, II and P-III.

Table 2 - Km and Vmax determination using BAEE as substrate.

\begin{tabular}{|c|c|c|c|}
\hline Inhibitor & $\mathbf{K m}(\mathbf{m M})$ & $\operatorname{Vmax}\left(\mu \operatorname{mols} \mathrm{L}^{-1} \mathbf{s}^{-1}\right)$ & Kcat $\mathrm{s}^{-1}$ \\
\hline- & 17.9 & 22.20 & 28.50 \\
\hline $\mathrm{I}$ & 17.9 & 6.41 & 8.04 \\
\hline- & 20.0 & 22.73 & 28.10 \\
\hline II & 4.02 & 4.05 & 4.73 \\
\hline- & 20.8 & 23.80 & 29.00 \\
\hline III & 11.4 & 12.80 & 15.80 \\
\hline
\end{tabular}

Conditions: BAEE in $\mathrm{KCl} 0.3 \mathrm{M}$, pH kept at 6.0 with tris at $25^{\circ} \mathrm{C}$. Enzyme concentration from 1 to $2 \times 10^{-6} \mathrm{M}$, activated with DTE and filtered in Sephadex G-25. 


\section{DISCUSSION}

Protease inhibitors are important elements of plant defense in response to insect predation and some of them act in infections by nematodes. Protease inhibitors of proteic nature are generally categorized according to the class of protease that they inhibit. Papain is inhibited by phytocistatins inhibitors (Koiwa et al., 1997). Nevertheless, different forms of inhibitors endoproteinase interaction were studied, unveiling even a new type of papain inhibitor, a kind of tiroglobuline (Polgar, 1984). The chymopapain aminoacid sequence was thoroughly studied, but some reports described isoforms of latex proteins (Polgar, 1984; Barret and Buttle, 1985; Brocklehurst and Salih, 1985). It could be possible that these isoforms were a result of different steps of chymopapain manufacturing during the latex coagulation. The occurrence of some peptides in Carica papaya latex, collected in various incisions times of green fruits, were analyzed. SDS-PAGE showed variation in the composition of these peptides during latex coagulation and that these variations could let loose the enzyme inactivation present up to two seconds after the fruit injury (Moutim et al., 1999). A different method for papain precipitation was used and, through a systematic kinetic study, the presence of natural inhibitors complexed to papain was shown (Monti et al., 2000), in accordance with the results of Moutim et al. (1999). In the present work, three fractions with inhibitory effect of the esterase activity of the papain were isolated from fresh latex by filtration in gel and ionic exchange chromatography. Inhibitors of proteolytic enzymes have been reported from other vegetable sources and also from animals. However, the method used for papain precipitation and consequently the fractions with inhibitory activity was different from those described in the literature because the inhibitors isolation after fresh latex collection of Carica papaya was immediately brought to the lab and its $\mathrm{pH}$ was adjusted to 9.0 and after centrifugation was dialyzed with distilled water. The dialysis water was lyophilized and the powder obtained corresponded to the starting inhibitory material for the separation. Similarly, a proteinase inhibitor (PEPI) was isolated and purified from passion fruit (Passiflora edulis Sim) juice by DEAE-Sephacel and trypsin-Sepharose 4B column chromatography. PEPI inhibited trypsin and chymotrypsin activities but did not inhibit papain activity (Hashiguschi et al., 1993). The fractions with papain inhibitory activity obtained in the present study identified as inhibitor I and II, showed negative reaction with ninhydrin, but on the other hand fraction of P-III showed positive reaction with ninhydrin, confirming the peptide binding. Through kinetic studies it was shown that inhibitor I showed non-competitive inhibition, inhibitors II and P-III showed incompetitive inhibition.

\section{CONCLUSIONS}

Three fractions with inhibitory effect of the esterase activity of the papain were isolated from fresh latex. The fraction identified as P-III showed positive reaction with ninhydrin, confirming the peptide nature. The inhibitor I was identified with non-competitive inhibition, while II and P-III exhibited incompetitive inhibition.

\section{ACKNOWLEDGEMENTS}

We are thankful to Dr. A. A. Simões for providing laboratory facilities, without which it could not be possible to complete this work.

\section{RESUMO}

Este trabalho apresenta novos dados sobre inibidores naturais de papaína. O látex fresco de frutos verdes de Carica papaya foi coletado pela manhã em plantações da região de Araraquara, SP, Brasil e imediatamente transportado ao laboratório em banho de gelo. Três frações com efeito inibitório da atividade esterásica da papaína foram isoladas a partir do látex fresco, através de diálise, filtração em Sephadex G-25 e cromatografia em SP-Sephadex C-25. As frações isoladas identificadas como inibidores I e II, mostraram reação negativa à ninidrina; entretanto, a fração identificada como P-III mostrou reação positiva. Dados cinéticos revelaram inibição não-competitiva (inibidor I) e incompetitiva (inibidores II e P-III).

\section{REFERENCES}

Barrett, A. J. and Buttle, D. J. (1985), Names and numbers of papaya proteinases. Biochem. J., 228, 527. 
Bode, W. and Huber, R. (2000), Structural basis of the endoproteinase-protein inhibitor interaction. Biochem. Biophys. Acta, 1477, 241-252.

Brocklehurst, K. and Salih, E. (1985), Fresh non-fruit latex of Carica papaya contains papain, multiple forms of chymopapain and papaya proteinase $\Omega$. Biochem. J., 228, 525-527.

Dubois, T.; Jacquet, A.; Schnek, A. G. and Looze, Y. (1988), The thiol proteinases from the latex of Carica papaya L. Biol. Chem. Hoppe-Seyler, 369, 733-740.

Dubois, T.; Kleinschmidt, T.; Schned, A. G.; Looze, Y. and Braunitzer, G. (1988), The thiol proteinases from the latex of Carica papaya L.: the primary structure of proteinase omega. Biol. Chem. HoppeSeyler, 369, 741-754.

Fernandes, K. V. S.; Campos, F. A. P.; Do-Val, R. R. and Xavier, F. J. (1991), The expression of papain inhibitors during development of cowpea seeds. Plant Sci., 74, 179-184.

Hanada, K.; Tamai, M.; Yamagishi, M.; Omura, S.; Sawada, J. and Tanaka, I. (1978), Isolation and characterization of E-64, a new thiol protease inhibitor. Agric. Biol. Chem., 42, 523-528.

Hashiguschi, T.; Inai, M. and Ohkubo, M. (1993), Proteinase inhibitor in passion fruit. Biotechnol., 46, 409-415.

Heinrikson, R. L. and Kézdy, F. J. (1976), Acidic cysteine protease inhibitors from pineapple Stem. In: Lorand, L. (Ed.). Methods Enzymolog. New York : Academic Press. pp.740-751.

Hines, M. E.; Osuala, C. I. and Nielsen, S. S. (1992), Screening for cysteine proteinase inhibitor activity in legume seeds. J. Sci. Food Agriculture, 59, 555-557.

Jacobsen, C. F.; Leonis, J.; Linderstrom-Lang, K. and Ottesen, M. (1957), The pH-stat and its use in biochemistry. Method. Biochem. Anal., 4, 171-210.

Järvinen, M. (1979), Purification and some characteristics of 2 human-serum proteins inhibiting papain and other thiol proteinases. FEBS Lett., 108, 461-464.

Kimmel, J. R. and Smith, E. L. (1954), Crystalline papain. I. - Preparation specificity and activation. J. Biol. Chem., 207, 515-530.

Kirsh, J. R. and Igelströn, M. (1966), The kinetics of papain catalyzed hydrolysis of esters of carobenzoxyglycine. Evidence for an acyl-enzyme intermediate. Biochemistry, 5, 783-791.

Koiwa, H.; Bressan, R. A. and Hasegawa, P. M. (1997), Regulation of protease inhibitors and plant defense. Trends Plant Sci., 2, 379-384.

Kopitar, M.; Brzin, J.; Zvonar, T.; Locnikar, P.; Kregar, I. and Turk, V. (1978), Inhibition studies of an intracellular inhibitor on thiol proteinases. FEBS Lett., 91, 355-359.

Learmonth, E.M. (1951), Soybean trypsin inhibitor. J. Sci. Food Agr., 2, 447-454.

Lineweaver, H. and Burk, D. (1934), The determination of enzyme dissociation constants. J. Am. Chem. Soc., 56, 658-666.
Mitchel, R. E. J.; Claiken, I. M. and Smith, E. L. J. (1970), The complete amino acid sequence of papain. J. Biol. Chem., 245, 3485-3492.

Monti, R.; Basilio, C. A.; Trevisan, H. C. and Contiero, J. (2000), Purification of papain from fresh latex of Carica papaya. Braz. Arch. Biol. Techn., 43, 501-507. Mosolov, V. V. (1994), Proteins inhibitors of proteolyticenzymes. Bioorganicheskaya Khimiya, 20, 153-161.

Moutim, V.; Silva, L. G.; Lopes, M. T. P.; Fernandes, G. W. and Salas, C. E. (1999), Spontaneous processing of peptides during coagulation of latex from Carica papaya. Plant Sci., 142, 115-121.

Norioka, S.; Omichi, K.; Ikenaka, T. (1982), Purification and characterization of protease inhibitors from peanuts (Arachis hypogaea). J. Biochem., 91, 1427-1434.

Polgar, L. (1984), Problems of classification of papaya latex proteinases. Biochem. J., 221, 555-556.

Rele, M. V.; Vartak, H. G. and Jagannathan, V. (1980), Proteinase inhibitors from Vigna unguiculata subsp. cylindrica I-Ocurrence of thiol proteinase inhibitors in plants and purification from Vigna unguiculata subsp. cylindrica. Arch. Biochem. Biophys., 204, 117-128.

Ritonja, A.; Buttle, D. J.; Rawlings, N. D.; Turk, V. and Barrett, A. J. (1989), Papaya proteinase IV amino acid sequence. FEBS Lett., 258, 109-112.

Ryan, C. A. and An, G. (1988), Molecular biology of wound-inducible proteinase inhibitors in plants. Plant Cell Environ., 11, 345-349.

Sasaki, M.; Taniguschi, K. and Minakata, K. (1981), Multimolecular forms of thiol proteinase inhibitor in human plasma. J. Biochem., 89, 169.

Tamai, M.; Adachi, T.; Oguma, K.; Morimoto, S.; Hanada, K.; Ohmura, S. and Ohzeki, M. (1981), Study on thiol protease inhibitors. A. Relationship between structure and papain inhibitory activity of epoxysuccinyl amino acid derivatives. Agric. Biol. Chem. Tokyo, 45, 675-679.

Taniguchi, K.; Ito, J. and Sasaki, M. (1981), Partial purification and properties of urinary thiol proteinase inhibitors. J. Biochem. Tokyo, 89, 179-184.

Vartak, H. G.; Rele, M. V. and Jagannathan, V. (1980), Proteinase inhibitors from Vigna unguiculata subsp. cylindrica, III-Properties and kinetics of inhibitors of papain, subtilisin and trypsin. Arch. Biochem. Biophys., 204, 134-140.

Watson, C.; Yaguchi, M. and Lynn, K. R. (1990), The amino acid sequence of chymopapain from Carica papaya. Biochem. J., 266, 75-81.

Whitaker, J. R. and Bender, M. L. (1965), Catalysed hydrolisis of alpha-N-benzoyl-L-arginine ethyl ester and alpha-N-benzoil-L-arginineamide. J. Am. Chem. Soc., 87, 2728. 